\title{
News from Austria
}

\section{Personal}

On reaching the age of 70 , Hugo Hantsch resigned as director of the Historical Institute of the University of Vienna. He had studied under Harold Steinacker at the University of Innsbruck and with Heinrich von Srbik at the University of Vienna before succeeding him in 1946. His extensive writings include works in cultural history, early modern history, and Austrian history to the end of the First World War. He has had a large number of students.

Hantsch's successor at the University of Vienna is Heinrich Lutz, who, after studying with Franz Schnabel at the University of Munich, was appointed assistant at the German Historical Institute at Rome in 1953. There he cooperated in editing the "Nuncio Reports from Germany." While at Rome he concentrated his research on the sixteenth century. In 1961 he qualified himself as university lecturer at the University of Munich. In the same year he was made professor of modern history (Ordinarius für Geschichte der Neuzeit) at the University of Saarbrücken. In 1966 he was appointed to his present position at the University of Vienna. In addition to making important contributions to the history of the sixteenth century, Lutz has concentrated his studies especially on topics dealing with nineteenth- and twentieth-century cultural history, as well as problems of Catholicism in the twentieth century.

In 1966 Hans Wagner was appointed professor of Austrian history at the University of Salzburg.

In 1967 Erika Weinzierl was appointed to the chair of Austrian history (with special emphasis on contemporary history) at the University of Salzburg.

In 1968 Heinrich Schmidinger became professor of medieval history and auxiliary sciences at the University of Salzburg and director of the Austrian Institute at Rome.

Early in 1969 Gerald Stourzh, of the Free University of Berlin, returned to the University of Vienna to succeed Friedrich Engel-Janosi as professor of modern history.

Beginning with the academic year 1969-1970 Adam Wan-

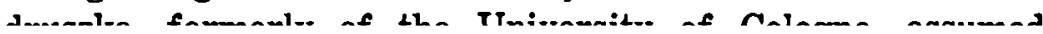


his duties as professor of Austrian history at the University of Vienna.

Johann Rainer, formerly of the University of Rome, was appointed professor of Austrian history at the University of Innsbruck at the beginning of the academic year 1968-1969.

In 1964-1965 Karl Gutkas passed all the requirements for lecturing about Austrian history in a university. The title of his Habilitations-dissertation was Geschichte des Landes Niederösterreich. During the same year Gustav Otruba also qualified himself for a university position in economic and social history with a Habilitations-dissertation on Forschungen zur Industriegeschichte österreichs.

Herwig Wolfram, whose Habilitations-dissertation was Intitulatio-Lateinische Königs- und Fürstentitel bis zum Ende des 8. Jahrhunderts, qualified himself in the academic year 1966-1967 for a lectureship in medieval history and auxiliary sciences. During the academic year 1968-1969 Wolfram was visiting professor at the University of California (Los Angeles).

In 1968-1969 Hans Schaller was made docent of medieval history and auxiliary sciences. $\mathrm{He}$ is currently teaching at the University of Salzburg.

In 1968 Michael Mitterauer qualified himself for lecturing on economic and social history. His Habilitations-dissertation, entitled Zollfreiheit und Marktbereich, deals with economic problems of the middle ages.

In July, 1968, Othmar Hageneder was awarded the venia legendi (Lehrbefugnis) for medieval history at the University of Vienna.

The newly-founded University for Social and Economic Studies (Hochschule für Sozial- und Wirtschaftswissenschaften), at Linz, opened its door to students in 1966, and Gustav Otruba was appointed to the chair for social and economic history. In 1968 a chair was established for modern and contemporary history (Lehrkanzel für Neuere Geschichte und Zeitgeschichte). Karl R. Stadler, formerly of the University of Nottingham, was appointed to fill it.

In 1967, when Hugo Hantsch resigned as director of the Commission for Modern History (Kommission für Neuere Geschichte) of the Austrian Academy of Sciences, Erich Zöllner replaced him. Hantsch continues to serve as chairman of the academy's Committee for the History of the 
Austro-Hungarian Monarchy (Kommission für die Geschichte der österreichisch-ungarischen Monarchie), which during the last years has energetically worked toward bringing out a multivolume history of the Habsburg monarchy from 1848 to 1918. After Alphons Lhotzky's unfortunate death, Hantsch replaced him on the Committee for Austrian History (Kommission für Geschichte Osterreichs).

In the fall of 1968 Alexander Novotny became chairman of the Institute for Austrian Studies (Institut für Osterreichkunde).

\section{Prizes}

The Innitzer Prize for 1966 was awarded jointly to Gerhard Silberbauer, for his work on österreichs Katholiken und die Arbeiterfrage, and Othmar Pickl, for his Das älteste Geschäftsbuch Österreichs. For 1967 the prize was given to Paul Zulehner for his Kirche und Austromarxismus.

\section{Meetings and Lectures}

The thirteenth historical conference of the Institute for Austrian Studies, which was held during Easter week of 1966, was devoted to the general theme "Austria, 1867-1914." The lectures and discussions were centered around the nationality question and the cultural, military, economic, and social problems of the Francis Joseph era.

The Institute for Contemporary History (Institut für Zeitgeschichte) of the University of Vienna, which is directed by Ludwig Jedlicka, arranged a lecture in June, 1966, by General Hans Speidel on the subject, "Ludwig Beck and Erwin Rommel. Military Leadership and a Troubled Conscience."

The fifth international seminar conducted by the Viennese Europahaus in July, 1966, had as its general theme "The Danubian Realm, Yesterday, Today, and Tomorrow." Ninetyfive academicians and students from fourteen different countries took part in the lectures and discussions. There were sizable delegations from six universities of the former Danubian monarchy - the Universities of Budapest, Graz, Cracow, Prague, Vienna, and Zagreb. The papers read at the seminar and the contributions made during the discussions were published by Europa Verlag in 1967 in a work entitled Donauraum -gestern, heute, morgen.

An international symposium was held in Baden bei Wien in 
September, 1966, under the chairmanship of Richard Plaschka, director of the Austrian Eastern and Southeastern European Institute (Osterreichisches Ost- und Südosteuropa-Institut). Over twenty Czech, German, and Austrian historians attended this meeting to discuss "The Problems of Nationalism in the Bohemian Lands in the Nineteenth and Twentieth Centuries." Josef Koči, of the Historical Institute of the Czechoslovakian Academy of Sciences, and Friedrich Prinz, of the University of Saarbrücken, were the main speakers at the first session, which dealt with "The Czech National Revival and Nationalism." Koči designated the extinction of the medieval feudal nation and the transition to a modern nation with a Czech national consciousness as the chief attributes of the Czech national rebirth. Prinz pointed out that economic factors were at the root of the antagonisms which existed between Czech and German bourgeois nationalisms. Whereas the German middle class was definitely an industrial bourgeoisie, its Czech counterpart was an agrarian bourgeoisie.

At the second session, which was devoted to "The Development of German Nationalism in the Bohemian Lands in the Nineteenth Century," papers were read by Karl Richter, of the Collegium Carolinum, at Munich, and Jiři Kořalka, of the Historical Institute of the Czechoslovakian Academy of Sciences. Both speakers emphasized the fact that antagonisms did not develop between the Czech and German bourgeoisie before the second half of the nineteenth century.

For the third session Koloman Gajan, of the University of Prague, and Helmut Slapnicka, of Linz, presented papers on "Nationalism and the Czech and German Parties in Czechoslovakia during the Interwar Years." Gajan divided the era into three periods: (1) the one immediately following the war (1918-1920), when both camps resorted to positions that conflicted sharply with each other; (2) the years between 1920 and 1933, when there was a certain degree of cooperation between the Czech and German parties; and (3) the era after Hitler's coming to power, when the differences between them became more acrimonious (1933-1939). Slapnicka pointed to the large number of parties and presented an excellent analysis of the party programs of the separate political power groups.

Pavel Reiman, director of the Institute for the History of the Communist Party of Czechoslovakia, and Heinrich Kuhn, of the Sudetendeutsches Archiv, at Munich, were the speakers 
for the final session on "The Communist Party in Czechoslovakia during the Interwar Period." Reiman emphasized the fact that the Communist Party of Czechoslovakia was the only international party in the country and pointed out that it discarded the fiction of a Czechoslovak nation in 1924. Kuhn added that the Communist Party's attitude towards the nationality question was influenced by the overall tactical considerations of the party.

Fritz Fellner, of the University of Salzburg, gave a series of lectures in various American universities in the spring of 1966. In the fall of 1968 he made a lecture tour in Hungary, England, and Italy.

The fourteenth historical conference of the Institute for Austrian Studies (Institut für Osterreichkunde) was held in March, 1967. The actual problems of contemporary Austria were emphasized by the speakers. The general theme of the conference was "Austria, its Tasks and Accomplishments."

Together with the Austrian Eastern and Southeastern European Institute, the Institute for Contemporary History invited Hans-Adolf Jacobsen, of the University of Bonn, to lecture in Vienna. Jacobsen spoke on "The Program and Structure of National Socialist Foreign Policy between 1919 and 1939, especially with Reference to Southeastern Europe."

In the spring of 1967 Ludwig Jedlicka was invited to give a lecture on "Emperor Francis Joseph" at the University of Bonn.

The ninth Austrian Historical Conference was held at Linz on September 4-8, 1967. The deliberations at the ten different section meetings of the conference ranged in subject from prehistory and ancient history to universal history, regional history, legal and economic history, and to colonization, the Slavs and Eastern Europe, folklore, historical geography, numismatics, heraldry, and genealogy. The lectures and discussions at this conference were published in Vol. XVII (1968) of the Veröffentlichungen des Verbandes österreichischer Geschichtsvereine.

In the fall of 1967 Hans Wagner delivered a lecture at the Austrian Cultural Institute at Paris on "The Influence of Gallicanism and Jansenism in Austria." This lecture was published in Vol. XI (1967) of Österreich in Geschichte und Literatur. 
A symposium dealing with the compromise of 1867 and its consequences, which was organized by the Institute for Austrian Studies, was held in Graz during the first half of October, 1967. In arranging the lectures, the Institute made an interesting and successful effort to have presented both the Hungarian and Austrian points of view on the chosen themes. István Diószegi handled political problems at the time of the Compromise of 1867 from the Hungarian point of view, and Alexander Novotny treated the same subject from the Austrian standpoint. In a similar manner, the topic "SocialEconomic Problems at the Time of the Compromise" was dealt with by György Ránki and Ferdinand Tremel and the one on "Cultural Problems at the Time of the Ausgleich" by Lászl6 Mátrai and Anton Klein. The symposium was continued at Pécs (Fünfkirchen) on March 25-27, 1968. Here the lectures dealt especially with the political, socio-economic, and cultural consequences of the Compromise.

On invitation by the Institute for Contemporary History, Vladimir Turok, of the Academy of Sciences at Moscow, spoke in Vienna in December, 1967, on "The Austrian Republic in Russian Historiography."

The fifteenth historical conference of the Institute for Austrian Studies was held at St. Pölten on April 7-10, 1968. "Austria 1913-1938" was the topic discussed at the meeting.

During the latter part of October, 1968, an international conference on the causes and consequences of the breakup of the Habsburg monarchy in 1918 was held at Vienna. The symposium was organized by the Austrian Eastern and Southeastern European Institute, with the support of the federal ministry of education. Four different topics were considered at the meeting: (1) diplomatic developments from the Fourteen Points to the collapse of the monarchy; (2) the social and economic effects of the war and the political repercussions of the disintegration of the empire on the enemy powers; (3) the military causes and results of the breakup of the monarchy; and (4) the democratization of the Central Powers that resulted from the establishment of the Successor States. Scholars from twelve European countries and from the United States (Robert A. Kann, Ivo J. Lederer, and R. John Rath) delivered lectures and participated in the discussions, which are now being edited for publication by the Austrian Eastern and Southeastern European Institute. 


\section{Publications}

In 1965 the fifth volume of the Veröffentlichungen des Instituts für Osteuropäische Geschichte und Südostforschungen of the University of Vienna-the Wiener Archiv für Geschichte des Slawentums und Osteuropas-was published, under the title Studien zur Geschichte Osteuropas, as a memorial volume in honor of Heinrich Felix Schmid.

In 1967 Christoph Thienen-Adlerflycht's Graf Leo Thun im Vormärz. Grundlagen des böhmischen Konservativismus im Kaisertum Österreich was published as Vol. VI of the Veröfentlichungen des Osterreichischen Ost- und Südosteuropa Instituts.

Vol. VI of the Veröffentlichungen des Instituts für Osteuropäische Geschichte und Südostforschung, which was published in 1967, is devoted to Bertold Picard's Das Gesandtschaftswesen Ostmitteleuropas in der frühen Neuzeit. Beiträge zur Geschichte der Diplomatie in der 1. Hälfte des sechzehnten Jahrhunderts nach den Aufzeichnungen des Freiherrn Sigmund von Herberstein.

Two volumes of the Veröffentlichungen der Komission für Neuere Geschichte were published between 1965 and 1968: Julius Marx, Die wirtschaftlichen Ursachen der Revolution von 1848 in österreich (Vol. LI) ; and Clemens MetternichWilhelmine von Sagan. Ein Briefwechsel 1813-1815, edited by the Czech historian Maria Ullrichová. In his volume in the series, Marx describes the pre-1848 administration on the basis of a rich collection of documents and attempts to show how the material problems of that era helped to prepare the way for revolution. In the near future the Kommission für Neuere Geschichte plans to publish the last volume of Friedrich Walter's Zentralverwaltung ; Peter Schuster's Das österreichbild bei Henry Wickham Steed; and the Korrespondenz Ferdinands I., edited by Herwig Wolfram.

The Committee for Austrian History of the Austrian Academy of Sciences, which before his death was headed by Alfons Lhotzky, has assumed responsibility for preparing a new history of Austria which will take into account the historical picture since 1918 and will emphasize the continuity of Austria from the time of the early Habsburgs to the twentieth-century republic. In addition, non-political factors are to be discussed at much greater length than they were in the Geschichte österreichs by Huber and Redlich. In fact, a recognized need 
for greater emphasis on non-political concerns provided the main impulse for the initiation of the project. Lhotzky was able to finish only the first part of the second volume of the projected history. It was published as No. 1 of the Veröffentlichungen der Kommission für Geschichte Osterreichs under the title Geschichte österreichs 1281-1358 (Graz: Böhlau, 1967). Lhotzky's death and the loss of several other potential collaborators have somewhat delayed the progress of the project. Nonetheless, it has been continued along the lines prescribed by Lhotzky. Meanwhile, a series of special studies, dealing mainly with the medieval history of Austria, has been carried on under the auspices of the Commission. Carl Pfaff's Scriptorium und Bibliothek des Klosters Mondsee im hohen Mittelalter has been published as No. 2 of the Veröffentlichungen and Wolfgang Hilger's Ikonographie Kaiser Ferdinands I. (1503-1564) as No. 3.

Between 1965 and 1968 a number of important studies were published in the Österreich Archiv series. Among them were Theodor Veiter's Die Italiener in der österreichisch-ungarischen Monarchie (Vienna: Verlag für Geschichte und Politik, 1965), which is a well-documented political and constitutional study not only of the larger national groups in the Tyrol and in Trieste but also of all the Italians who lived within the borders of the Habsburg monarchy. Helmut Rumpler's Das Völkermanifest Kaiser Karls vom 16. Oktober 1918. Letzter Versuch zur Rettung des Habsburger-Reiches was published in 1966 (for a review, see Austrian History Yearbook, Vol. III, Pt. 3 [1967], pp. 357-358). The next volume in the series was Robert A. Kann's Die Sixtusaffäre und die geheimen Friedensverhandlungen österreich-Ungarns im Ersten Weltkrieg. In the first part the author gives an account of the Sixtus Affair which he had personally discovered and which has already been published elsewhere. In the second part Kann makes a thorough analysis of the Sixtus negotiations and fits them into the larger context of other peace efforts. In Die Gemeindeselbstverwaltung im alten österreich 1848-1918 (Vienna: Verlag für Geschichte und Politik, 1968), another volume in österreich Archiv, the Czech legal historian Jiří Klabouch presents the results of a study of municipal self-administration and its place in and political ties with the government-an important subject that has heretofore been almost entirely neglected. The next volume scheduled for publication in the 
series is Ingeborg Meckling's Die Außenpolitik des Grafen Czernin.

Helmut Rumpler's Max Hussarek. Nationalitäten und $\mathrm{Na}$ tionalitätenpolitik in österreich im Sommer des Jahres 1918 was published as Vol. IV of Studien zur Geschichte der österreichisch-ungarischen Monarchie. Vol. V of the Studien is Walter Wagner's Geschichte des k. k. Kriegsministeriums, Vol. I. In it, the author examines, on the basis of a large number of documents, the changes in the leadership of the army between 1848 and 1867 and their close connection with the political changes of this period. Vol. VI is devoted to Moritz Csáky's Der Kulturkampf in Ungarn. In this interesting study, Csáky brings to the reader a deep understanding for the problems of Hungary, as well as for those of the monarchy as a whole. The last volume of the Studien published up to now is Christoph Führ's Das k. u. k. Armeeoberkommando und die Innenpolitik in österreich 1914-17. It also deals with internal political problems. The author discloses the quarrels between the military and the civil administration, especially in regard to the nationality policies followed during the first half of the First World War. The next volumes to be published in the Studien zur Geschichte der österreichisch-ungarischen Monarchie will be devoted to diplomatic topics. Wolfdieter Bihl will deal with Der Friede von Brest-Litovsk und österreich-Ungarn, and Waltraud Heindl will examine Die Außenpolitik Graf Buol-Schauensteins bis 1852.

In 1968 two volumes were published in the Veröffentlichungen der Arbeitsgemeinschaft für Geschichte der Arbeiterbewegung in Osterreich. Published as Vol. IV of this series was Rudolf Neck's Arbeiterschaft und Staat im Ersten Weltkrieg, Vol. II-a collection of sources emphasizing the problems revolving around the January, 1918, strike. Other documents in the volume deal with the Stockholm Conference of the summer of 1917, the militarization of businesses dealing in war materials, and revolutionary propaganda in foreign countries. This volume contains an extremely rich collection of valuable sources for evaluating the last phase of the history of the monarchy.

Vol. V of the Veröffentlichungen is Herbert Steiner's Die Gebrïder Scheu, which contains voluminous materials about the earlier period of the history of Austrian Social Democracy.

Under the auspices of the International Commission for 
Comparative Ecclesiastical History of the International Committee of Historical Sciences, Gerhard Rill compiled the volume on Austria for the Bibliographie de la réforme 1450-1648, which was published in Leiden in 1967. The Bibliographie de la réforme includes scholarly publications from several countries on the subject of the Reformation which were published between January 1, 1940, and December 31, 1960.

Towards the end of 1966 the Wiener Domverlag published the Kirchenhistorische Atlas von österreich, edited by Ernst Bernleithner.

The Institut für kirchliche Zeitgeschichte Salzburg, the director of which is Erika Weinzierl, published Hirtenbriefe 1965 aus Deutschland, österreich und der Schweiz (a collection of the episcopal communications of the German-speaking countries) in 1966. In 1967 it published Paul Michael Zulehner's Kirche und Austromarxismus-a sociological study of the relationship of the Catholic Church with the state and society during the past hundred years.

Another volume dealing with the same kind of problem is the two-volume study entitled Kirche in österreich 1918-65, which was edited by F. Klostermann et al. In it over forty collaborators have attempted to make as comprehensive an evaluation as possible of the present-day situation of the Church, as well as of its historical development. The contributions fall into the following categories: (1) ecclesiasticalreligious life; (2) the many different attitudes of the Church towards state and society; and (3) Catholic movements and organizations.

Another important contribution to Austrian contemporary history is the collection of documents in Zur Reform der österreichischen Innenpolitik 1955-65, edited by René Marcic, Erhard Mock, Franz-Martin Schmölz, and Erika Weinzierl, published in two volumes in 1966-68 by Europa Verlag in Vienna and Pustet Verlag in Salzburg.

Among the books whose publication was inspired by the semicentennial of the creation of the Austrian Republic, mention should be made of the following cooperative work of Austrian experts on jurisprudence: Die Republik österreich. Gestalt und Funktion ihrer Verfassung, edited by Hans Klecatsky. This work deals with the historical origins and nature of the Austrian federal constitution. At the same time, its aim is to show how much the constitutional instrument 
created at that time stood in contradiction to political reality and how it would be possible to free the basic merits of the constitution from its antiquated structure. The contributors to the volume are Adolf Merkl, Hans Kelsen, René Marcic, Alfred Kobzina, Felix Ermacora, Herbert Schambeck, Alfred Verdross, Johannes Messner, and Hans Klecatsky.

Since 1967 the Institute for Contemporary History of the University of Vienna has been microfilming documents dealing with the political sentences of Austrian courts. Up to now 100,000 pages have been copied, most of them on $16 \mathrm{~mm}$. frames.

Gabriele Hindinger's Das Kriegsende und der Wiederaufbau demokratischer Verhältnisse in Oberösterreich im Jahr 1945 was published by Verlag Brüder Hollinek in 1968 as Vol. VI of the Publikationen des Osterreichischen Instituts für Zeitgeschichte und Instituts für Zeitgeschichte of the University of Vienna.

A volume on Österreichische Parteiprogramme 1868-1966, edited by Klaus Berchtold, Felix Ermacora's assistant in the Institute for Political and Administrative Law of the Law School of the University of Vienna, was published in 1967. The work consists of a collection of programmatic writings and manifestos that have never been brought together in a single place and thus is an important source and reference work.

The first volume published in the Schriftenreihe des Osterreichischen Ost- und Südosteuropa-Instituts, edited by Richard Georg Plaschka and Karlheinz Mack, was Friedrich EngelJanosi and Helmut Rumpler's Probleme der franzisko-josephinischen Zeit 1848-1916. Published in this book, which was brought out in 1967, are a number of lectures delivered at the University of Vienna in 1966: "Der Monarch und seine Ratgeber," by Friedrich Engel-Janosi; "Kaiser Franz Joseph und die Aussenpolitik," by Hugo Hantsch; "Osterreichs innere Politik," by Alexander Novotny; "Arbeiterbewegung und soziale Frage 1848-1918," by Rudolf Neck; "Das Heerwesen," by Johann Christoph Allmayer-Beck; "Die Stellung Ungarns in der Monarchie," by Péter Hanák; and "Osterreich-Ungarn im Spiegel der öffentlichen Meinung Europas," by Jacques Droz.

The oisterreichische Historische Bibliographie-Austrian Historical Bibliography 1965 was published in 1967 by Erich 
H. Boehm, of the International Bibliographical Center, of Santa Barbara, California, and Fritz Fellner, of the Historical Institute of the University of Salzburg. Compiled by Herbert Paulhart, with the assistance of Rudolf G. Ardelt and Günther Hödl, the project was initiated by its two publishers. The Osterreichische Historische Bibliographie is intended to serve as an indication of how bibliographical gaps can be closed in countries that still have no national bibliographies. It includes works on both history and its auxiliary sciences. The 1966 issue, published and compiled by the same persons as the one for 1965, was brought out in 1969. The volumes for 1967 and 1968 are now being completed.

Fritz Fellner is area editor for Historical Abstracts. The articles on Austria are being compiled by members of the Historical Institute of the University of Salzburg.

A group of Austrian and Hungarian historians are working together to prepare for publication the minutes of the Austrian ministerial council from 1848 to 1867 . The Hungarian editorial committee is composed of Gyösö Ember, Ervin Pamlényi, and Péter Hanák. Friedrich Engel-Janosi, Heinrich Lutz, and Richard Georg Plaschka are the members of the Austrian committee.

The Institute for Social and Economic History of the University of Vienna, carrying on an extensive research program on behalf of the Austrian Academy of Sciences, is compiling and editing the österreichische Städtebuch. Herbert Knittler is in charge of the project. The first volume-the one on Upper Austria-was published in 1968.

On commission of the Central Association of Austrian Savings Banks, the Institute has compiled and edited the österreichisches Sparkassenlexikon and a work entitled 150 Jahre Sparkassenwesen. The compiler of these works, which will soon be published, is Hedwig Pavelka.

The Institute is preparing Vol. II, Pt. 2 of Die Wiener Ringstrasse. Bild einer Epoche, edited by Renate WagnerRieger. This particular volume, which is being prepared by Hannes Stekl and Franz Baltzarek, will be published under the title Wirtschafts- und sozialgeschichtliche Studien zur Wiener Ringstrasse.

Heinrich Mejzlik has undertaken the editing of a history of iron-metallurgy and cartels in the iron industry in the AustroHungarian monarchy. This project will be carried out in co- 
operation with the appropriate sections of the Czechoslovakian and Hungarian Academies of Science.

The Institute has also assumed responsibility for editing the fourth volume of the Handbuch der europäischen Sozialund Wirtschaftsgeschichte, which will cover the period between the middle of the seventeenth and the middle of the nineteenth century. The individual articles of this work will be written by appropriate specialists in various European countries. In addition, the Institute has agreed to provide the regional advisory board for the fields of Austria, the Habsburg monarchy, and the Successor States for the Wirtschaft und Gesellschaft im Industriezeitalter encyclopedia edited by Karl Erich Born, of Tübingen. Alfred Hoffmann is directing both projects.

The following works have recently been published in the Wiener Forschungen zur Wirtschafts- und Sozialgeschichte, brought out under the auspices of the Institute for Economic and Social History: Grete Merk's Zwei Pioniere der österreichischen Industrie Alois Miesbach und Heinrich Drasche (Vol. I of the above series), which was published in 1967 ; and, as Vol. II, Hedwig Pavelka's Englisch-österreichische Wirtschaftsbeziehungen in der ersten Hälfte des 19. Jahrhunderts, which was brought out early in 1968.

\section{Documentation Archive of the Austrian Resistance Movement}

The Documentation Archive of the Austrian Resistance Movement, which was founded on March 13, 1963, and which is directed by a 90-member board of trustees, has moved to a new location in the old Vienna City Hall on Wipplingerstrasse. During recent years the document holdings of the Archive have steadily increased. They include original manuscripts, photographs, films, eyewitness accounts, xerox copies, and notes. Among the persons who have worked in the Archive are doctoral students of Ludwig Jedlicka and Fritz Fellner, who have used the documents housed there for their dissertations. An exhibit assembled by the Documentation Archive has been displayed with great success, both in Austria and abroad. In March, 1968, it was exhibited in Moscow.

The Institute of Labor History

The first academic institute in Austria devoted to the his- 
tory and the study of the labor movement has been established at the new University of Linz, which specializes in the social and economic sciences. Initiated by the Ludwig Boltzmann Society for the Promotion of Research in Austria, the new Institute is under the direction of Karl R. Stadler, formerly of the University of Nottingham (England) and now professor of modern and contemporary history at the University of Linz. The Institute is working in cooperation with archives and other organizations, both in Austria and abroad, to encourage and assist research in and publication of works on labor history. It will be glad to hear from persons possessing material or engaged in research on any aspect of labor history, principally in Central and Eastern Europe. Interested persons should get in touch with Prof. Karl R. Stadler, University of Linz, 4045 Linz, Austria.

HORST HASELSTEINER University of Vienna and

Peter URBanitsch University of Vienna 